\title{
Infectious hypodermal and haematopoietic necrosis virus (IHHNV) in a hybrid penaeid prawn from tropical Australia
}

\author{
L. Owens ${ }^{1}$, I. G. Anderson ${ }^{2}$, M. Kenway ${ }^{3}$, L. Trott ${ }^{3}$, J. A. H. Benzie ${ }^{3}$ \\ ${ }^{1}$ Graduate School of Tropical Veterinary Science and Agriculture, PO James Cook University of North Queensland, \\ Townsville, Queensland 4811, Australia \\ ${ }^{2}$ Oonoonba Veterinary Laboratory, Department of Primary Industries, Townsville, Queensland 4811, Australia \\ ${ }^{3}$ Australian Instítute of Marine Science, PMB No. 3, Townsville Mail Centre, Queensland 4810, Australia
}

\begin{abstract}
Chronic low-grade mortalities became epizootic in a batch of Penaeus esculentus hybridised with Penaeus monodon prawns in Australia. Histopathological examination revealed extensive tissue changes in the gills, hypodermis, antennal gland, heart, ventral nerve cord, lymphoid organ, haematopoietic tissue, muscle and the connective tissue including the intertubule connective tissue in the hepatopancreas. Infected cells displayed intranuclear Cowdrey type A inclusions with marginated chromatin. The inclusions did not stain positively with Feulgen's DNA stain. Electron microscopy showed particles approximately $20 \mathrm{~nm}$ in diameter in the cytoplasm near the nucleus but no virions were observed intranuclearly. All the above characters are diagnostic for infectious hypodermal and haematopoietic necrosis virus (IHHNV). Other viruses that were infecting these prawns included lymphoidal parvovirus (LPV), Plebejus baculovirus (PBV), a haemocytic baculovirus and large icosahedral-shaped virus. This is the first record of IHHNV in a country that has not imported live prawns and suggests that $1 H H N V$ occurs naturally in the Australian Indo-West Pacific region.
\end{abstract}

\section{INTRODUCTION}

Due to zoogeographical isolation, aquatic animals in Australia were believed to have a relatively diseasefree state. This idea has been transferred from the terrestrial livestock industries, which are relatively disease-free. Furthermore, this belief has been reinforced by years of research on the prawn fisheries, where no large scale disease problems have been encountered. However, the crash in Taiwanese prawn farms (Rosenberry 1988) has led to an awareness of the role of disease in general and viruses in particular in penaeid aquaculture. Since Australia's penaeid aquaculture industries were worth about $A \$ 12$ million in 1990-91 (Treadwell et al. 1992), there has been some effort to redefine our viral status.

In Australia, hepatopancreatic parvovirus (HPV) was first described in 1985 (Paynter et al. 1985); a Monodon-type baculovirus, Plebejus baculovirus (PBV), was described in 1987 (Lester et al. 1987); and a new parvolike virus, lymphoidal parvovirus (LPV), was discovered in 1991 (Owens et al. 1991). LPV had many similarities to infectious hypodermal and haematopoietic necrosis virus (IHHNV) but did not readily produce the pathognomonic Cowdrey type A intranuclear inclusions (hereafter abbreviated to Cowdrey A). Both viruses infected tissues of mesodermal and ectodermal origin, with IHHNV being more tissue polytrophic than LPV. IHHNV is one of the most devastating viruses of prawns, particularly in Penaeus stylirostris, whilst some losses occur in both Penaeus vannamei and Penaeus monodon (Lightner 1988). Recently, IHHNV was found in Australia and this paper describes its discovery.

\section{MATERIAL AND METHODS}

Single spermatophores from male Penaeus esculentus were implanted in freshly moulted female $P$. monodon. The hatch rates varied between 0 and $4 \%$. The interspecies hybrid larvae were reared in either $80 \mathrm{l}$ conical fibreglass tubs or $1 \mathrm{l}$ Imhoff cones suspended in a $28^{\circ} \mathrm{C}$ 
constant-temperature water bath. In both systems, larvae were stocked at $100 \mathrm{l}^{-1}$ and reared on a diet of Chaetoceros gracilis, Artemia and Frippak (registered trade name) microencapsulated particles and Frippak Flake. Larvae in the 11 cones were terminated at the PL1 (postlarvae 1) stage to establish survival rates, whilst those in the 80 l tubs were reared through until the PL20 stage. At this age, 2000 interspecies hybrids were stocked into a $5 \mathrm{t}, \mathrm{U}$-shaped larval tank and ted commercial prawn pellets according to the manufacturer's recommendations. After they had grown to $4 \mathrm{~g}, 400$ juvenile interspecies hybrids were transferred into a $10 \mathrm{t}$ maturation tank and the diet was supplemented by fresh squid.

Seawater ( $34 \mathrm{ppt}$ ) for the 2 rearing stages was settled for at least $24 \mathrm{~h}$, filtered through sand and cartridge filters down to $1 \mu \mathrm{m}$ before being treated by ultraviolet light ( $254 \mathrm{~nm}$ ) at $9600 \mu \mathrm{W} \mathrm{cm} \mathrm{cm}^{-2}$. The maturation tank was maintained on a recirculation system topped up daily with $10 \%$ new seawater

Moribund prawns were collected just after the major epizootic (Day 100; see Fig. 1) from holding tanks and fixed in Davidson's fixative. Histological processing and staining followed the methods outlined by Culling et al. (1985). For electron microscopy, diced gill tissue was fixed in $2.5 \%$ glutaldehyde $/ 2 \%$ paraformaldehyde in cacodylate buffer or $10 \%$ formalin and postfixed in $1 \%$ osmium tetroxide. The tissue was dehydrated and mounted in Spurr's (Tm) resin. Sections were cut on an LKB Ultratome at $500 \AA(50 \mathrm{~nm})$, stained with uranyl acetate $/ 70 \%$ methanol and lead citrate and viewed at $80 \mathrm{kV}$ on a Joel 2000FX transmission electron microscope.

\section{RESULTS}

\section{Gross signs}

Survival of the interspecies hybrids to the PL1 stage was greater than $80 \%$ with no obvious abnormalities detected. Although densities were not measured during the subsequent postlarval stages until PL20, survival was estimated to be greater than $50 \%$.

When the prawns reached approximately 3 to $4 \mathrm{~g}$, the major mortality occurred (Fig. 1) and consequently the survivors were moved to the maturation tank. There, chronic low-grade mortalities persisted over a 1 mo period. Approximately 5 prawns were dying every day when the prawns were 5 to $10 \mathrm{~g}$. The prawns became weak, then stopped moving, and died. There was no noticeable change in coloration of the prawns, with the interspecies hybrids still reflecting a mixture of their parental colours and patterns. Fouling with epicommensals was not noticeable. However, the gills had many small melanised foci.

The mortality curve of the interspecies hybrids was compared to the mortality curve of Penaeus stylirostris as described by Lightner et al. (1983) (Fig. 1). The $P$. stylirostris epizootic occurred in much younger prawns than the interspecific hybrids, so the curves were transposed horizontally until the $50 \%$ mortality point was common. When the shape of the 2 curves was tested with the Kolomogorov-Smirnov goodnessof-fit test, they were identical ( $\mathrm{K}-\mathrm{S}=0.03, \mathrm{p}>0.98)$.

\section{Histopathology}

Single, rounded, intranuclear, eosinophilic occlusions were present in the hepatopancreatocytes of some of the prawns. The lesions are typical of PBV infections (Lester et al. 1987). The intensity of infection was low and was considered not to contribute to the mortalities

All the major mesodermal and ectodermal tissues showed prominent Cowdrey type A intranuclear inclusions. The cells in the hypodermal tissues of the gills (Fig. 2) and oral appendages, the brachiostegial membrane, the general hypodermis (Fig 3), antennal gland (Fig. 4), heart (Fig. 5), the gonads (Fig. 6), the lymphoid organ (Fig. 7), the connective tissue (Fig. 8), the haematopoietic tissue (Fig. 9), rarely the skeletal muscle (Fig. 10), and nerve cord (Fig. 11) displayed inclusions. The tissues/organs most heavily infected 

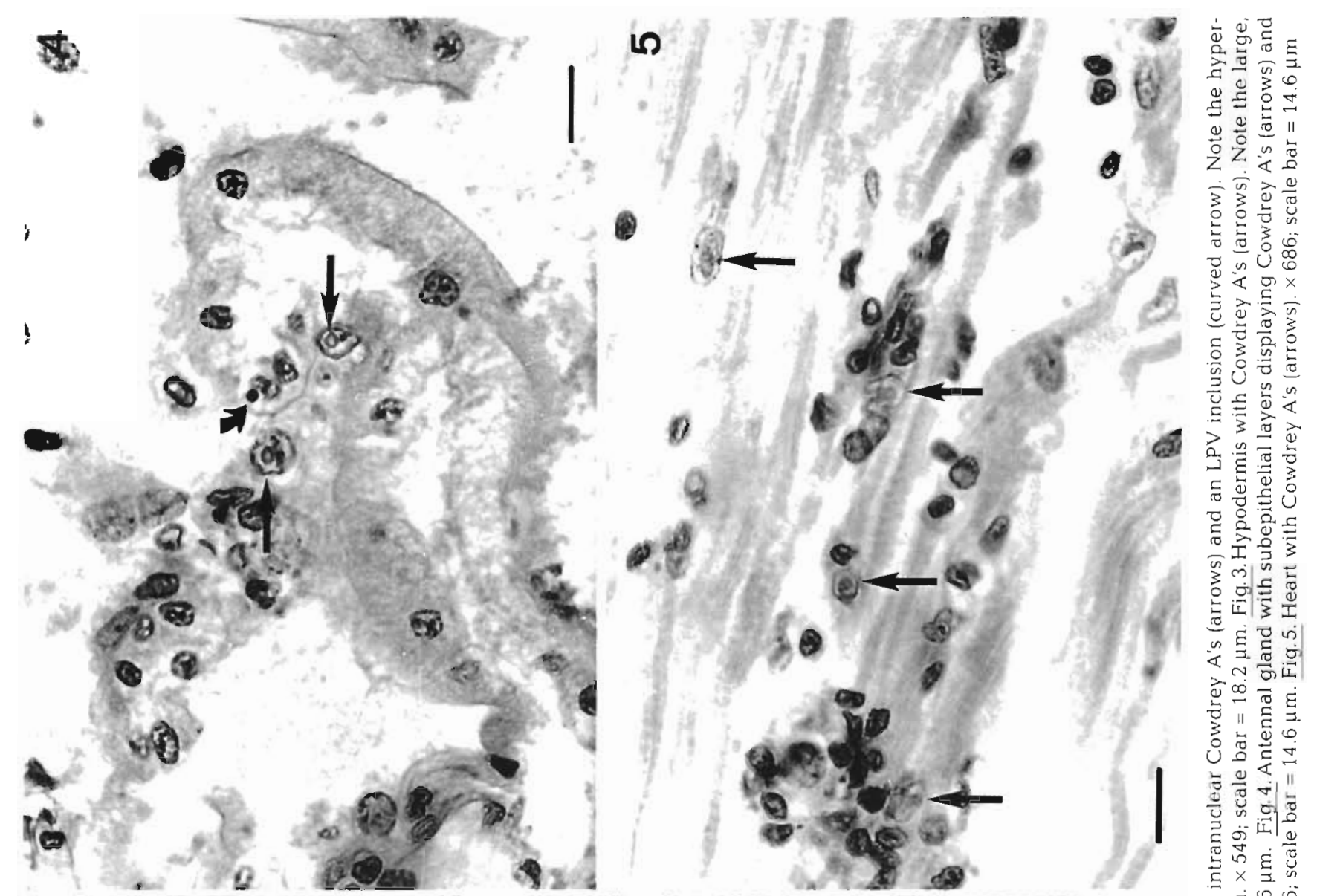

$$
\text { a.d }
$$<smiles>CCCCCCC</smiles>

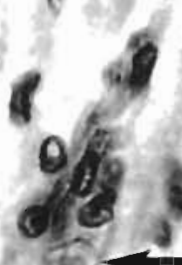

(1)

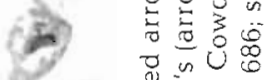

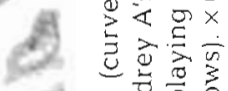

考要言

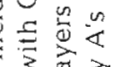

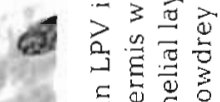

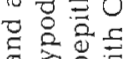

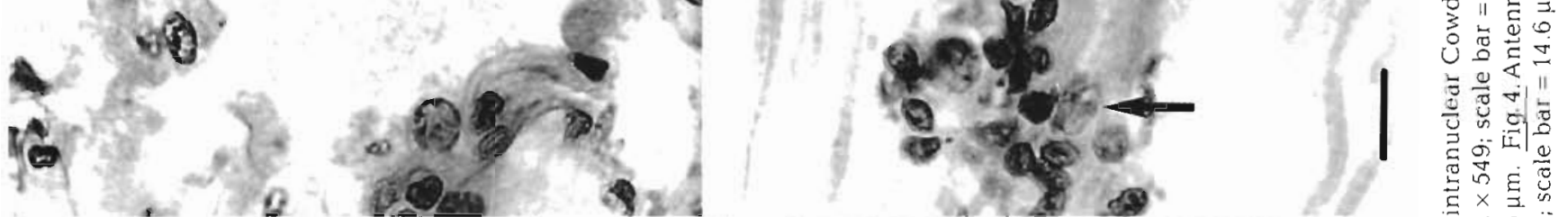

(N)

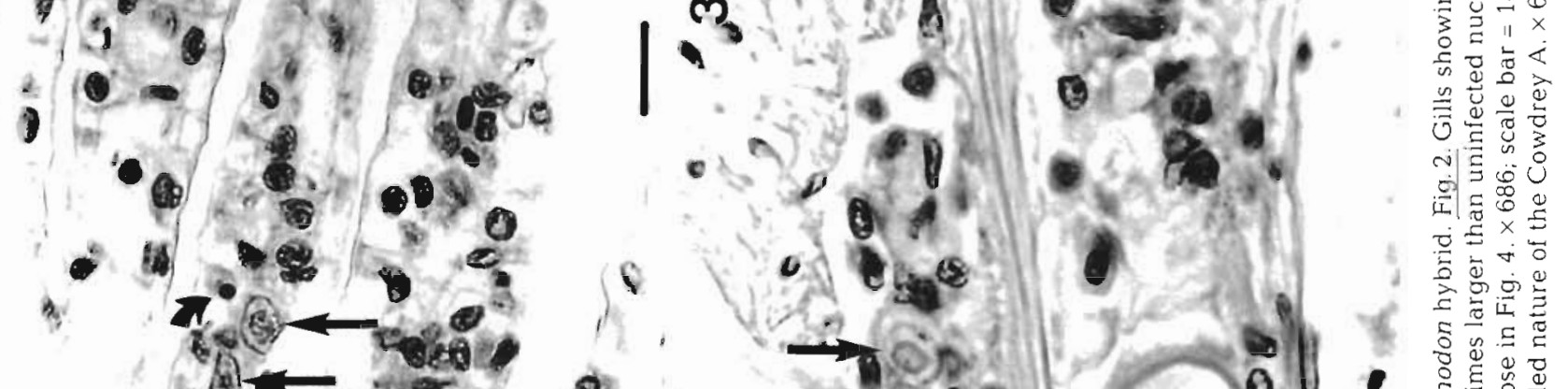

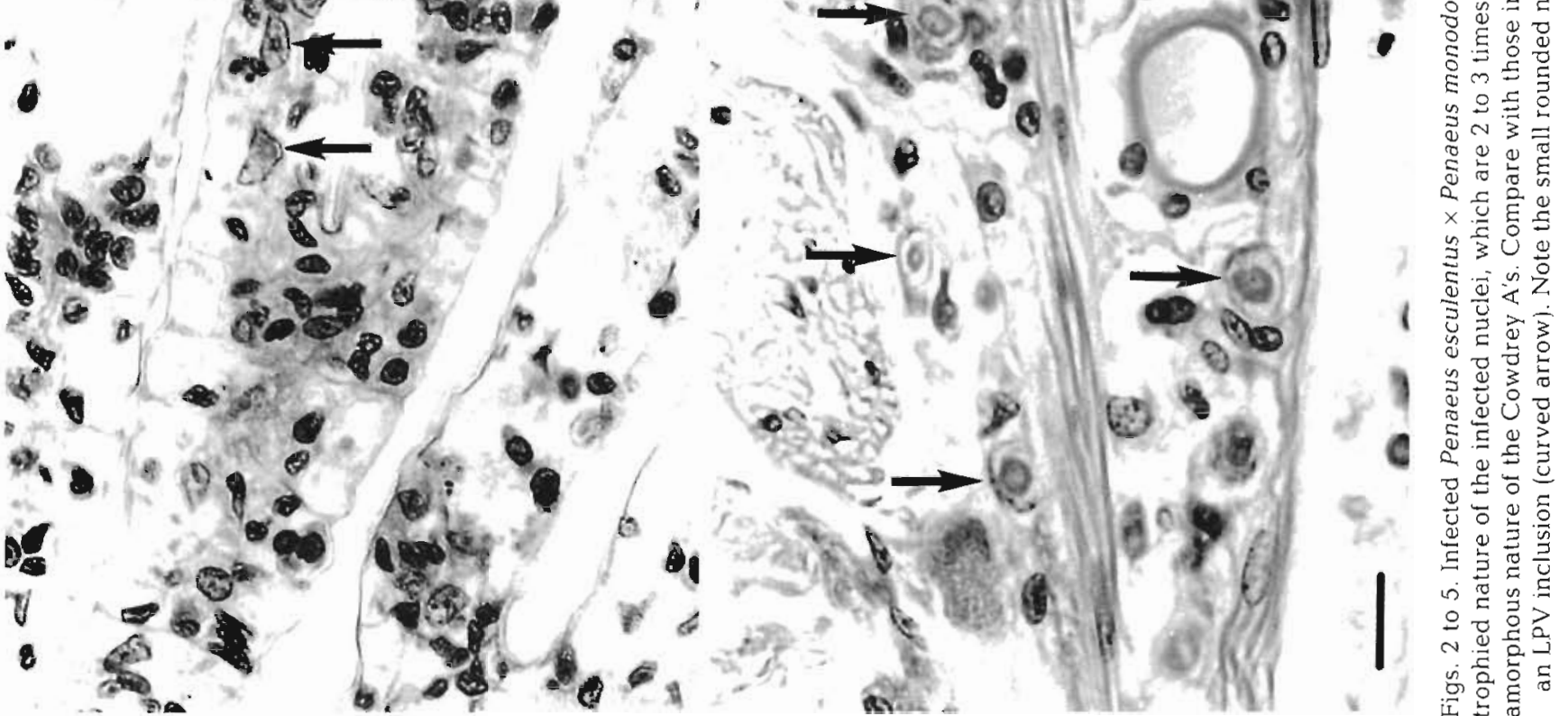




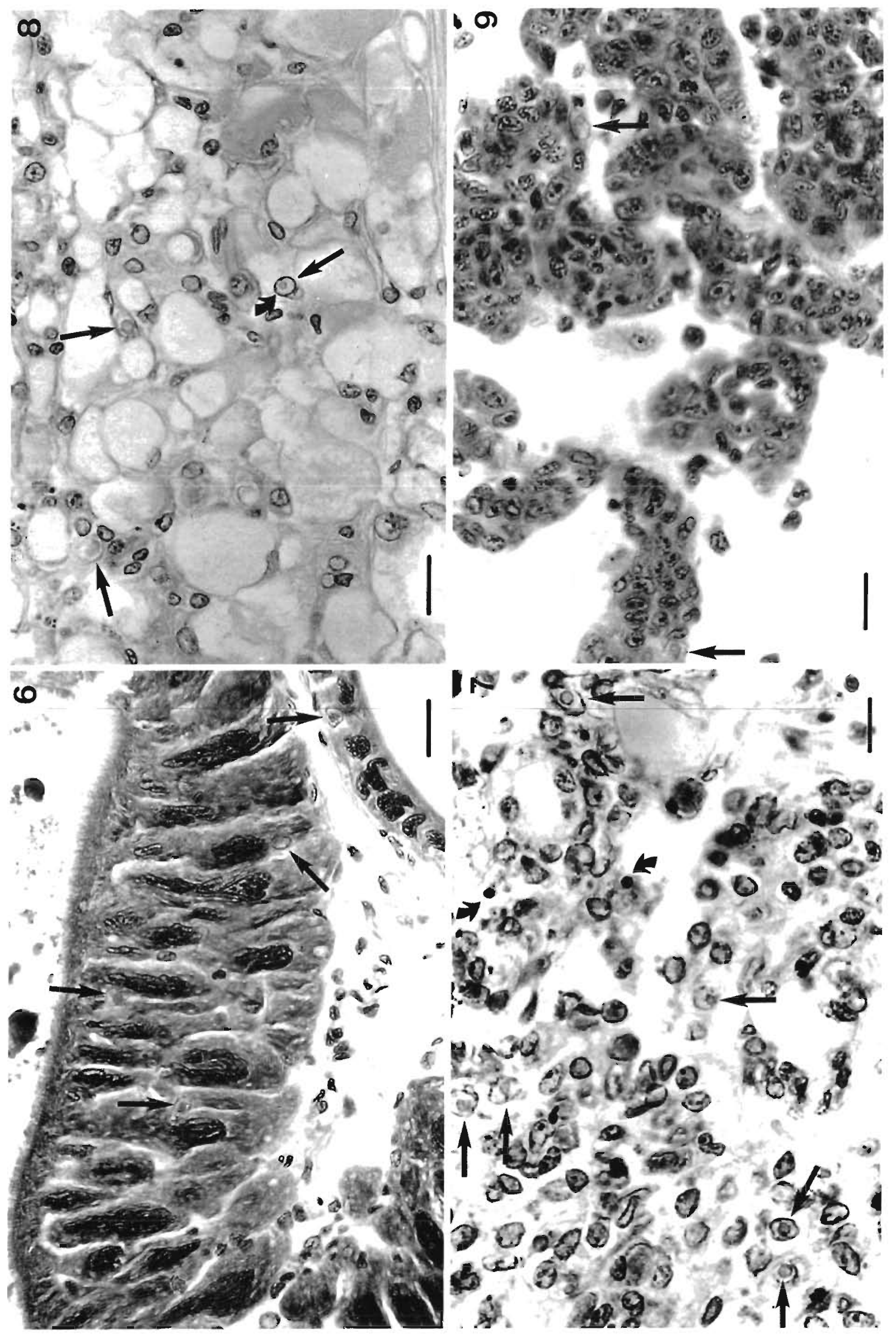

可苛

要

号

过总

$x_{\infty}$

i

正

$\therefore$ 送

要点

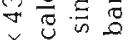

की

要通

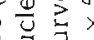

远政

$3 \stackrel{0}{0}$

$0, \Xi$

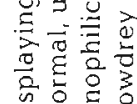

n 0 \&

式

की

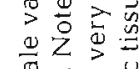

$\sum_{i=0} \bar{n}_{0}$

证完

ن $\overline{0} \Xi$

昰总垔

号它家

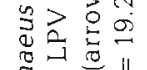

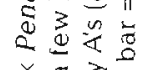
$\times$ 舟 드유

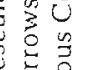
政宗 


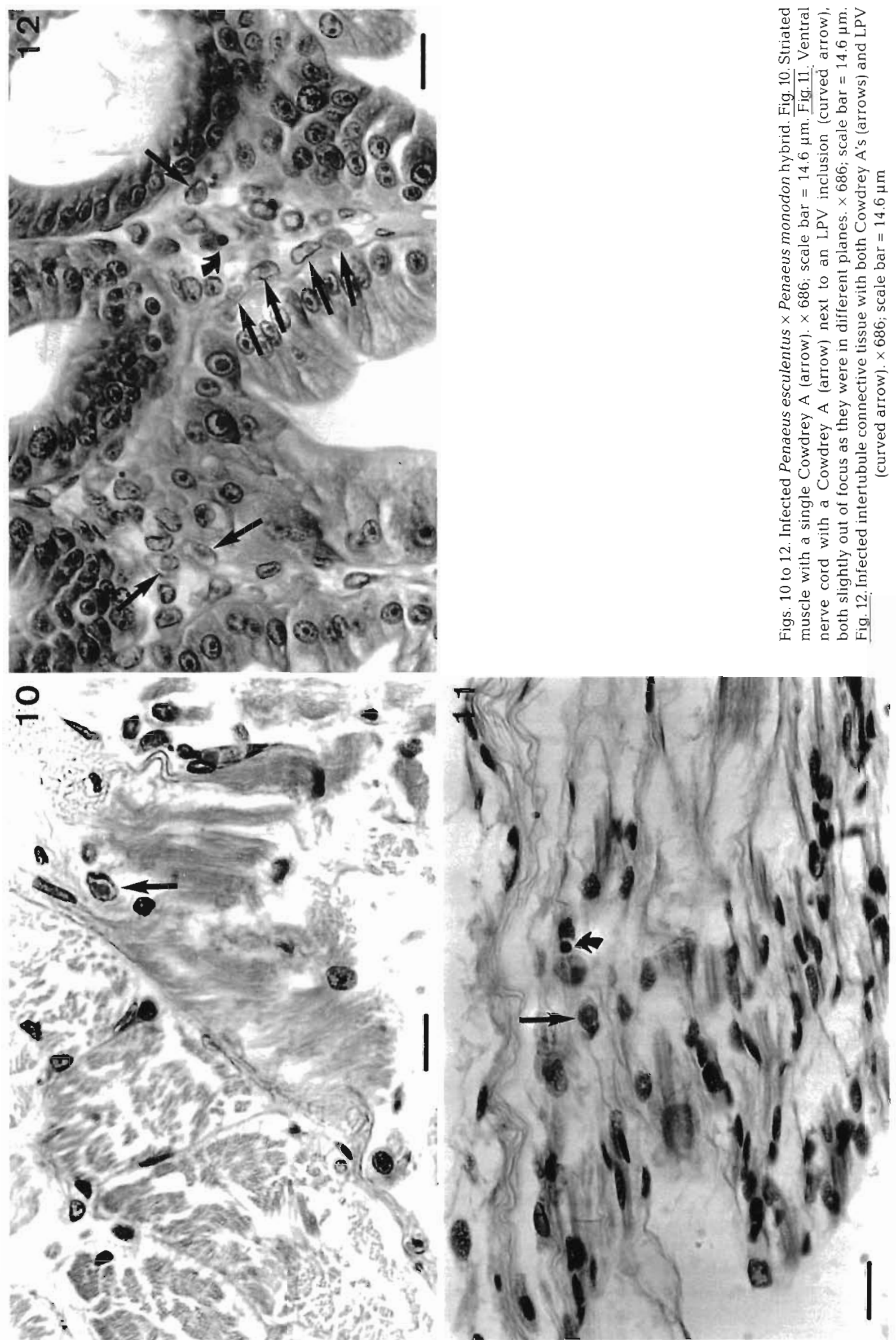


were the lymphoid organ and the connective tissue throughout the prawn. Every cell of the lymphoid organ was infected, including the tubule cells. In some prawns, the connective tissue in-between the hepatopancreatic tubules was also infected (Fig. 12). This elicited a haemocytic infiltration which started to separate adjoining tubules. Also present in this area were inclusions of LPV. The hearts of some prawns had focal collections of haemocytes and in some prawns melanised nodules were contained within haemocyte aggregations in the connective tissue. None of the gut tissues displayed the inclusion bodies.

All the above tissues also displayed much less commonly the round, basophilic intranuclear inclusions of LPV. IHHNV is a much more aggressive virus, with approximately 30 cells infected with IHHNV to every one infected with LPV. Whilst the Cowdrey A inclusions were Feulgen negative, the LPV basophilic inclusion stained positively with Feulgen.

The first sign of an infected cell is margination of the chromatin which leads to the nucleus becoming clear The cell becomes slightly to markedly hypertrophic. Then the nucleolus, which retains its rounded shape, becomes eosinophilic. The nucleolus is, at this stage, very similar in size to both the LPV inclusion and the IHHNV basophilic inclusion. Many infected cells displayed this rounded, eosinophilic inclusion in a large, clear hypertrophied nucleus (Figs. 4 \& 8). The intranuclear inclusion then grows non-symmetrically in size to give the typical Cowdrey $\mathrm{A}$.

\section{Electron microscopy}

With transmission electron microscopy (TEM), 3 possible virus types were visualised: small IHHNV-like virions; large $(900 \times 136 \mathrm{~nm})$, cytoplasmic, haemocytic baculovirus virions, and large (100 to $180 \mathrm{~nm})$, cytoplasmic, un-enveloped, icosahedral virions (cf. an iridiovirus). The last 2 virion types will be described in a separate paper

Nuclei of cells presumptively displaying Cowdrey A's had a homogeneous mass that almost filled the whole nucleus (Fig. 13). There was no ring of marginated chromatin but rather a wide separation of the 2 layers of the nuclear membrane the nuclear envelope). The intranuclear matrix could not be resolved into virions even when magnified up to 50000 times. However, in the cytoplasm of cells with presumptive Cowdrey A inclusions, there was a ring of nonenveloped particles about 18 to $20 \mathrm{~nm}$ in diameter around the outer nuclear membrane in particular (Fig. 14), and around other vacuoles and swollen mitochondria. The nuclear pores were also filled with these particles and in one cell there appeared to be an outpouring of these particles from one of the nuclear pores (Fig. 14). It appears that assembly of the virions is taking place in the cytoplasm at the membrane boundaries. Some of the mitochondria of infected cells were greatly swollen, to almost one-third the size of the nucleus (Fig. 13). The picture is remarkably similar to Figs. 3 \& 4 of Lightner (1988) without the paracrystalline arrays, and to that of the densovirus from Carcinus mediterraneus (in Mari \& Bonami 1988: their Fig. 2)

As well as the Cowdrey A's, there were the perfectly rounded, electron-dense, intranuclear inclusion bodies of LPV (Fig. 15). Again the inner matrix could not be resolved into individual virions but it seemed to be finely granular. Similar to cells displaying Cowdrey A's, the chromatin was not marginated but rather appeared to be incorporated into the inclusion body (Fig. 16). A range of cells from newly infected to a full LPV inclusion body were found. Initially, there were cells with very dense and thickened chromatin, surrounded by a nuclear membrane in the process of splitting (Fig. 17). In one cell, a pocket in the chromatin contained virion-like particles (Fig. 17). Secondarily, only the centre of the nucleus was not electron-dense and the nuclear membrane was split along its whole length, except for the nuclear pores where the mem-

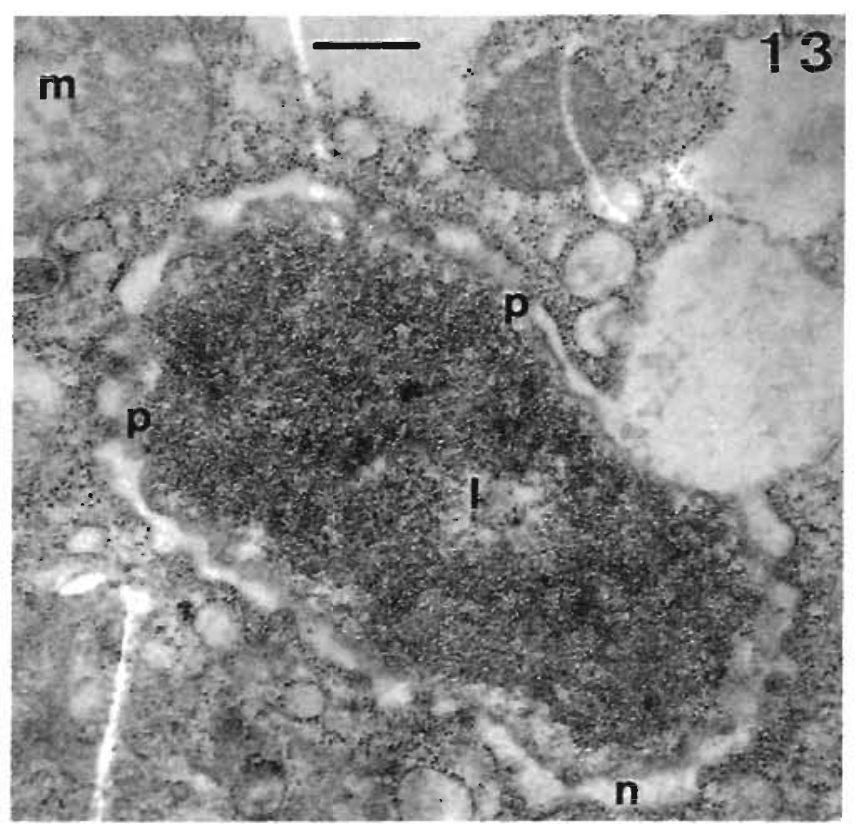

Fig. 13. Infected Penaeus esculentus $\times$ Penaeus monodon hybrid. A Cowdrey A intranuclear inclusion of IHHNV in the gills. The nuclear membranes ( $n$ ) are split except at the nuclear pores $(p)$ and there is a layer of particles around the nuclear membranes. The mitochondria $(m)$ are greatly swollen. TEM, $\times 21000$; scale bar $=476 \mathrm{~nm}$ 


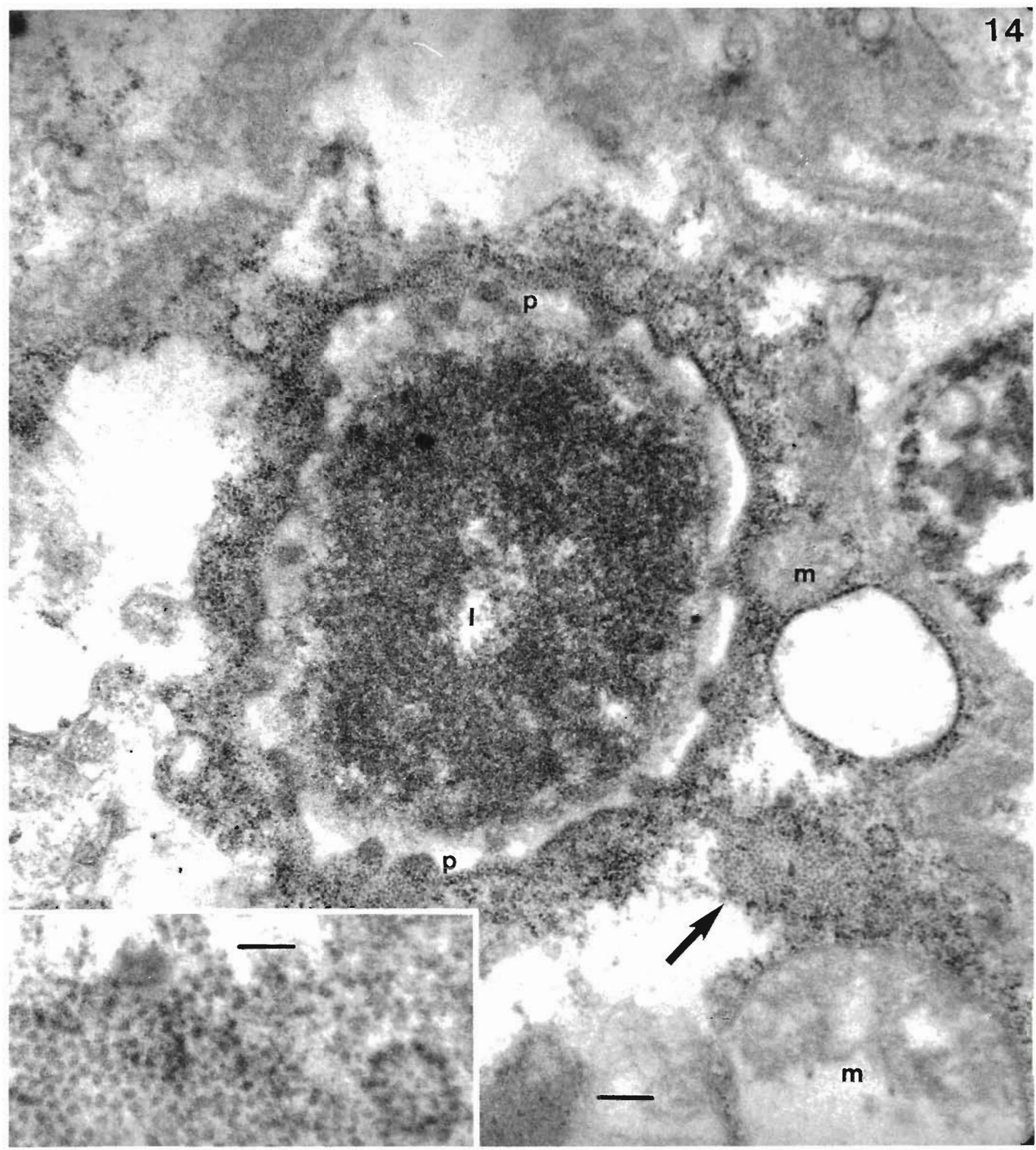

Fig. 14. Infected Penaeus esculentus $\times$ Penaeus monodon hybrid An enlargement of IHHNV infected gill cell with an inclusion (I). Note the many particles $18 \mathrm{~nm}$ in diameter around the nuclear membrane and associated with the nuclear pores (p) $V_{1}$ rions are apparently flowing out of the nuclear pore (arrow) Note the swollen mitochondna (m) close by TEM $\times 41000$; scale bar $=165 \mathrm{~nm}$. Inset shows non-enveloped virions at the arrow magnified 2.8 times. TEM, $\times 115000 ;$ scale bar $=462 \mathrm{~nm}$ 

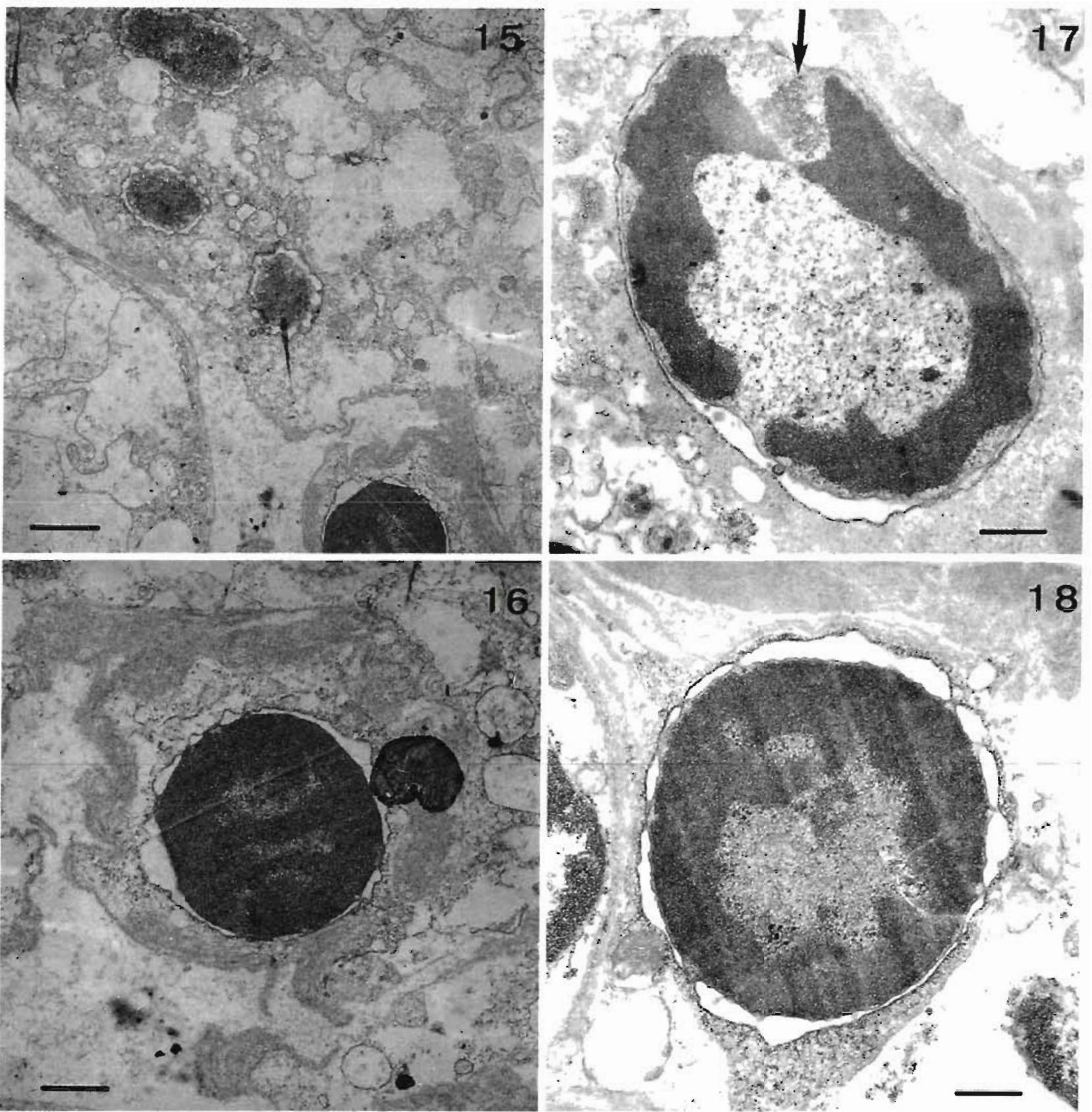

Figs. 15 to 18. Infected Penaeus esculentus $\times$ Penaeus monodon hybrid. Fig. 15. Three IHHNV infected cells (top) and one LPV intranuclear inclusion (bottom). TEM, $\times 5000$; scale bar $=2 \mu \mathrm{m}$. Fig. 16. Late-stage LPV inclusion with split nuclear membranes and chromatin incorporated into the inclusion body. TEM, $\times 10000 ;$ scale bar $=1 \mu \mathrm{m}$. Fig. 17. Early-stage presumptive LPV-infected nucleus with partial splitting of the nuclear membranes, hyperchromasia and a possible pocket of virions in the chromatin (arrow). TEM, $\times 17000$; scale bar $=588 \mathrm{~nm}$. Fig. 18. Midd]e stage of development of an LPV inclusion with the central portion of the nucleus not fully incorporated into the inclusion. TEM, $\times 17000$; scale bar $=588 \mathrm{~nm}$

branes are still joined (Fig. 18). Thirdly, the whole inclusion was electron-dense and it had small, irregularly positioned less dense parts to it (Fig. 16). No cells were seen that simultaneously displayed both types of pathology. Cells were either producing the LPV-type inclusion or the IHHNV-type.

\section{Immunodiagnostics}

Samples of gills identified histologically as having IHHNV-like lesions were sent to D. Lightner, University of Arizona (USA), to be tested with a monoclonal antibody to IHHNV in an ELISA. The tissue gave 
values of 38 to $71 \%$ intensity of the known IHHNV positive control (Lightner pers. comm).

\section{DISCUSSION}

The widespread, systemic occurrence of the Cowdrey A inclusion bodies, i.e. chromatin-haloed, Feulgen-negative, eosinophilic intranuclear inclusion bodies, is pathognomonic for IHHNV (Lightner et al. 1983, Lightner 1988) as no other prawn virus produces them in the same numbers. The diagnosis in the interspecific hybrid prawns was confirmed by TEM similarities between this case and IHHNV and by the results of the ELISA. Furthermore, the shapes of the mortality curves for IHHNV in Penaeus stylirostris and the interspecies hybrid were identical, but separated by age and size. Therefore, IHHNV or a virus that is indistinguishable from IHHNV within the current limits of diagnostic abilities is present in Australia.

As Australia has had a stringent quarantine policy, it is believed that no live prawns have been imported into the country, and the current case is a record of an endemic infection of IHHNV This is supported by the presence of low numbers of Cowdrey type A inclusions in wild-caught Penaeus merguiensis in northern Australia (Owens \& Hall-Mendelin 1990). Furthermore, culture facilities in SE Asia using only wild broodstock have been infected with IHHNV (Lightner et al. 1990). This gives support to the notion that the West Pacific may be the original geographical source for IHHNV.

Owens \& Hall-Mendelin (1990) noted that only prawns that did not have a long (geological time frame) exposure to IHHNV commonly produced Cowdrey A's whilst those that had been under long term (geological time frame) selection pressure did not. It took a new genetic mix, the cross between Penaeus esculentus and $P$. monodon, for IHHNV to become evident in Australia, even though research in this field has been ongoing since 1984. It is believed that had IHHNV occurred previously to this case, it would have been diagnosed.

Owens et al. (1991) recorded many similarities between IHHNV and LPV and concluded they were very closely related. There are 2 mutually exclusive hypotheses regarding these 2 viruses. Firstly, they could be 2 separate parvoviruses (Bonami et al. 1990, Owens et al. 1991). Alternatively, they could be the same parvovirus with different expression modes in different hosts or cells. The infection of prawns with both IHHNV and LPV should support the first hypothesis. However, cells of the interspecific hybrid prawns could be either expressing paternal, maternal or recombinant genes which may allow different cells in the same organ to express differently. All the surviving inter- specific hybrids were males, suggesting the female mix of genes was lethal, and the basis of the interspecific hybrids' resistance to the viral infections was compromised. Therefore, the data from this case do not support either hypothesis unequivocally.

The presence of IHHNV in Australia gives further evidence that in terms of disease, tropical marine Australia is part of the SE Asian faunal province. Over recent years, more and more disease organisms thought to be absent from Australia have been discovered here, e.g. the sequential discovery of the prawn viruses themselves (loc. cited), lymphocystis virus (Pearce et al. 1990), luminescent Vibrio harveyi disease of prawns (Muir 1990), bopyrid parasites (Owens 1990) and the pathogenic strain of the freshwater bacteria Edwardsiella tarda (in Eaves et al. 1990). It seems apparent that isolation of Australia's terrestrial and freshwater faunas is not matched in its marine fauna or consequent diseases.

Acknowledgements. We thank Dr D. V. Lightner for running samples through his IHHNV ELISA and the results presented herein. We also thank Chris Reid and Malcolm Shepard for technical assistance with histology and Steve de Beer for assistance with electron microscopy. This is Contribution No 826 from the Australian Institute of Marine Science.

\section{LITERATURE CITED}

Bonami, J. R., Trumper, B., Mari, J., Brehelin, M., Lightner, D. V. (1990). Purification and characterization of the infectious hypodermal and haematopoietic necrosis virus of shrimps. J. gen. Virol. 71: 2657-2664

Culling, C. F. A., Allison, R. T., Barr, W. T (1985). Cellular pathology techniques, 4th edn. Butterworths, London

Eaves, L. E., Ketterer, P. J., Anderson, I. G., Beumer, J. P. (1990). The isolation and identification of Edwardsiella tarda from a diseased native Australian eel (Anguilla reinhardtii). Aust. vet. J. 67:336-337

Lester, R. J. G., Doubrovsky, A., Paynter, J. L., Sambhi, S. K., Atherton, J. G. (1987). Light and electron microscope evidence of baculovirus infection in the prawn Penaeus plebejus. Dis, aquat. Org. 3: 217-219

Lightner, D. V. (1988). IHHN virus disease of penaeid shrimp. In: Sindermann, C. J., Lightner, D. V. (eds.) Disease diagnosis and control in North American marine aquaculture. Elsevier, Amsterdam, p. 11-15

Lightner, D. V., Bell, T. A., Redman, R. M. (1990). A review of the known hosts, geographic range and current diagnostic procedures for the virus diseases of cultured penaeid shrimp. Advances in Tropical Aquaculture, Tahiti (1989). Actes Colloq. 9: 113-126

Lightner, D. V., Redman, R. M., Bell, T A. (1983). Infectious hypodermal and haematopoietic necrosis, a newly recognised virus disease of penaeid shrimp. J. Invertebr. Pathol. 42: 62-70

Mari, J., Bonami, J-R. (1988). PC84, a parvo-like virus from the crab Carcinus mediterraneus: pathological aspects, ultrastructure of the agent and first biochemical characterisation. J. Invertebr. Pathol. 51: 145-156 
Muir, P. R. (1990\}. Factors affecting the survival of penaeids in culture with particular reference to the larval stages. Ph.D. dissertation, James Cook Unjversity of North Queensland. Townsville

Owens, L. (1990). Maricultural considerations of the zoogeography of the parasites of penaeid prawns. J. trop. Aquacult. 5: 33-39

Owens, L., de Beer, S., Smith, J. R. (1991). Lymphoidal parvolike virus from Australian penaeid prawns. Dis. aquat. Org. 11: 129-134

Owens, L., Hall-Mendelin, S. (1990). Recent advances in Australian penaeid diseases and pathology. Advances in Tropical Aquaculture, Tahiti (1989). Actes

Responsible Subject Editor: J. E. Stewart, Dartmouth, N.S., Canada
Collog. 9: $103-112$

Paynter, J L., Lightner, D. V., Lester, R. G. J. (1985). Prawn virus from juvenile Penaeus esculentus. In: Rothlisberg. P. C., Hill, B. J., Staples, D. J. (eds.) Second Aust, Nat. Prawn Sem. NPS2, Cleveland, Australia, p. 61-64

Pearce, M., Humphrey, J. D., Hyatt, A. D., Williams, L. M. (1990). Lymphocystis disease in captive barramundi Lates calcarifer. Aust. vet. J. 67: 144-145

Rosenberry, R. (1988). World shrimp farming 1988. Aquacult. Digest Feb. 1989: 1-24

Treadwell, R., McKelvie, L., Maquire, G. B. (1992). Potential for Australian Aquaculture. ABARE Research Report 92.2. Australian Government Publishing Service, Canberra

Manuscript first received: May 6, 1992

Revised version accepted: September 1, 1992 